WIDER Working Paper 2017/15

\title{
Industrial clusters
}

The case for Special Economic Zones in Africa

Carol Newman ${ }^{1}$ and John Page ${ }^{2}$

January 2017

In partnership with

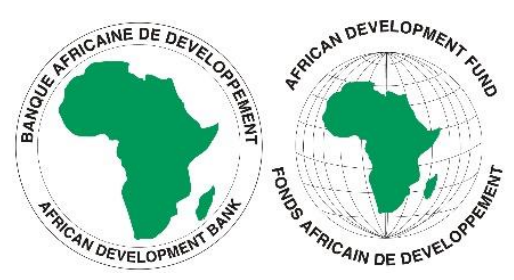

B Africa Growth Initiative at BROOKINGS

United Nations University World Institute for Development Economics Research 
Abstract: Firms tend to cluster in close geographic proximity to each other to benefit from reduced transport costs, shared inputs, and productivity spillovers due to learning and technology transfers. Evidence from low-income countries suggests that such agglomeration economies may be substantial in endogenously formed clusters. This raises the question of whether spatial industrial policies can be designed to facilitate clustering. In this paper, we consider the case for creating Special Economic Zones (SEZs) in Africa. We document at the country level the state of current SEZ programmes and the policy measures in place for their promotion. We give an overview of the evidence on their success and provide a set of policy recommendations to improve SEZs performance.

Keywords: agglomeration, Special Economic Zones, spatial industrial policy, Africa JEL classification: $\mathrm{O} 14, \mathrm{O} 25$

Acknowledgements: The paper was prepared as part of the UNU-WIDER research programme entitled 'Learning to compete (L2C)'. Our thanks to Kit Mattock and Cliona Mhogain for excellent research assistance. The usual caveats apply.

\footnotetext{
${ }^{1}$ Department of Economics, Trinity College Dublin, Ireland, corresponding author: cnewman@tcd.ie; ${ }^{2}$ Brookings Institution, Washington, DC, United States.

This study has been prepared within the UNU-WIDER project on 'Learning to compete (L2C)—accelerating industrial development in Africa'.
}

Copyright (C) UNU-WIDER 2017

Information and requests: publications@wider.unu.edu

ISSN 1798-7237 ISBN 978-92-9256-239-7

Typescript prepared by the Authors.

The United Nations University World Institute for Development Economics Research provides economic analysis and policy advice with the aim of promoting sustainable and equitable development. The Institute began operations in 1985 in Helsinki, Finland, as the first research and training centre of the United Nations University. Today it is a unique blend of think tank, research institute, and UN agency — providing a range of services from policy advice to governments as well as freely available original research.

The Institute is funded through income from an endowment fund with additional contributions to its work programme from Denmark, Finland, Sweden, and the United Kingdom.

Katajanokanlaituri 6 B, 00160 Helsinki, Finland

The views expressed in this paper are those of the author(s), and do not necessarily reflect the views of the Institute or the United Nations University, nor the programme/project donors. 
Manufacturing and service industries tend to be highly geographically concentrated in cities and industrial clusters. This is the case in both developed and developing economies. In France, the United Kingdom, and the United States 75-95 per cent of industry is clustered or concentrated relative to overall economic activity (World Bank 2009). In Viet Nam, large firms are surrounded by thousands of small enterprises in two major industrial clusters near Hanoi and Ho Chi Minh City. Thousands of small metalworking firms are cluster together in the Suame Magazine near Kumasi in Ghana and Arusha, Tanzania is home to a number of clusters of furniture manufacturers.

Areas of dense economic activity tend to prosper while others are left behind, largely because of the existence of agglomeration economies; these are productivity benefits that emerge from firms locating near one another. The strong evidence of benefits associated with agglomeration suggests that spatial industrial policies that influence the location choice of firms could be an effective tool in accelerating the pace of industrialization in low-income countries. In this paper, we examine the case for one specific instrument of spatial industrial policy in sub-Saharan Africa (SSA) establishing well-functioning Special Economic Zones (SEZs).

Africa's failure to industrialize has been the subject of much debate over the last decade and recently has received major attention. Sustainable Development Goal 9-adopted at the urging of African delegations - aims to 'build resilient infrastructure, promote sustainable industrialization and foster innovation'. The new President of the African Development Bank has flagged industrial development as one of his 'high five' top priorities, and in its 2016 Global Economic Prospects report the World Bank advocates 'creating the conditions for a more competitive manufacturing sector' in Africa as a response to dependence on commodities. How low-income countries in Africa can push the pace of industrialization has become an important question for policy makers and donors, alike.

Newman et al. (2016a, 2016b) highlight a number of emerging opportunities for Africa to industrialize. Economic changes that are taking place in Asia create a window of opportunity for late-industrializers elsewhere to enter into global markets. Rising costs, particularly in China, growing domestic demand in Asia and China's focus on investment and trade with Africa, open up significant opportunities for industrializing African nations. Coupled with this is the fact that the nature of manufacturing itself is changing. An increasing share of global trade in industry is made up of tasks within a value chain rather than finished products. This offers late-industrializers the opportunity to specialize in tasks that suit their underlying capabilities.

To seize these opportunities African governments will need new approaches to industrial policy. In this paper, we consider the role of SEZs as an instrument of industrial development. Public policies to bring a critical mass of investors into SEZs are often a prerequisite to breaking into global markets in manufacturing. We begin in Section 2 by defining agglomeration in a general sense and provide theoretical arguments for why firms tend to naturally cluster together. Following this we present some of the empirical evidence for agglomeration in low and low-middle income countries, its drivers and the impact of agglomeration on firm-level productivity. In Section 3 we consider the rationale for policies that actively encourage firms to cluster together through the establishment of SEZs, and we review the past performance of SEZs in Africa.

In Section 4, we give an overview of the current status of African SEZ programmes and summarize the various policy measures that are in place to promote them. Section 5 looks at recent efforts by 
China to support spatial industrial policy in Africa. China's Ministry of Commerce is undertaking the development of a number of 'official' SEZs, and a number of private Chinese investors have set up industrial zones outside of these official arrangements (Brautigam and Tang 2014). We review the status of these initiatives and use the case of Ethiopia, the country in which the Chinese SEZ model is most advanced, as a window into the possible costs and benefits of the new approach. In Section 6 we conclude by identifying some key factors that are needed for the success of SEZs in Africa.

\section{Agglomeration: definition, drivers and empirical evidence}

Agglomeration economies are the firm-level productivity gains that come from spatial concentration of economic activity. They can result from localization, which generally refers to productivity spillovers from locating in close geographic proximity to other producers, often of the same product or in the same value chain, or from urbanization, which are spillovers associated with locating in an area with more economic activity generally, usually urban centres. Here we focus on localization. Localization takes place because firms are drawn together for a variety of reasons mostly motivated by the desire to reduce the costs of transporting goods, people and ideas.

There are many examples of endogenously formed clusters in low and lower-middle income countries. For example, the Nnewi automotive parts cluster in Nigeria became a hub for local traders in automotive parts in the 1970s (Chete et al. 2014). When traders began importing machinery a vibrant cluster of manufacturers of automotive parts emerged. The key to its success was the transfer of technology through the training of Nigerian technicians in the new technologies and a focus on learning by doing and on-the-job training. Other examples include clusters of metalworking firms in Ghana and furniture manufacturers in Tanzania.

Marshall (1920) postulated three reasons why firms locate in close proximity to each other. First, transportation costs are reduced when firms are located close to their suppliers or customers. Suppliers of inputs located in large clusters of downstream firms can exploit economies of scale while downstream firms themselves benefit from timely delivery, lower inventory costs and specialized inputs tailored to their needs. The result is higher profits for upstream firms accompanied by easier access to a broader range of inputs for their customers. Second, workers with skills relevant to a particular sector will pool in areas where employment in that sector is high. Similarly, firms will be attracted to areas where there are a large number of workers (or managers) with skills relevant to their industry. This facilitates better matching of workers to jobs and makes it easier to hire new workers when labour demand increases. ${ }^{1}$ Third, knowledge spillovers, in particular informal exchanges of ideas between workers and entrepreneurs, are more likely when firms are in close geographic proximity (Krugman 1991; Fujita et al. 1999).

Duranton and Puga (2004) propose a different, albeit similar, classification of agglomeration effects into sharing, matching and learning. Sharing effects include risk pooling, gains from the availability of a greater variety of inputs and the use of common facilities. For example, industrial clusters can attract specialized trading firms that benefit small and medium firms trying to break into new markets (Sonobe and Otsuka 2006). Matching effects are associated with the matching of workers to jobs, while learning effects refer to the diffusion of knowledge. Firms that are located in close proximity to competitors can benefit from information sharing or can engage in collective

\footnotetext{
${ }^{1}$ See Helsley and Strange (1990). It could also be that a large pool of labour facilitates risk sharing making workers and firms better off when firms face idiosyncratic demand shocks (Krugman 1991; Overman and Puga 2010).
} 
action to overcome constraints such as contract enforcement, leading to efficiency gains (Schmitz 1995).

While there is a relatively large empirical literature documenting the productivity gains to firms from agglomeration in middle and high-income countries, less is known about the impact of spatial concentration on firm-level productivity in low-income countries. This is partly due to the problems in empirically identifying the productivity spillovers to firms that result from locating in a cluster. The identification of the impact of clustering on productivity is confounded by the possibility of self-selection; it is very difficult to determine whether the most productive firms choose to locate in clusters or whether it is clustering itself that increases firm-level productivity. ${ }^{2}$ Detailed firm-level panel data that includes the physical location of firms are required to identify the relationship between clustering and total factor productivity. Such data are hard to come by in low-income settings.

The joint African Development Bank, Brookings Institution, and UNU-WIDER project called 'Learning to Compete' was able to undertake detailed econometric studies in four low income countries: Cambodia, Ethiopia, Tunisia, and Viet Nam. Each study finds strong evidence for productivity spillovers associated with agglomeration. The largest effects were found in Viet Nam where firms located in small clusters experienced spillovers to a much greater extent than those in larger clusters, a result consistent with the hypothesis that localization economies predominate at early stages of industrial development. Interestingly, foreign-owned firms experienced the largest productivity spillovers from clustering, suggesting that policies to promote agglomeration are complementary to efforts to attract FDI (Chhair and Newman 2014; Howard et al. 2014; Howard et al. 2016; Siba et al. 2012).

Many of the country-level results are consistent with the view that clustering is associated with capability building for firms in low income countries (Sutton 2012). In Tunisia, there is evidence of agglomeration economies arising from the transmission of innovative ideas between firms located in close proximity to one another (Ayadi and Mattoussi 2014). In Cambodia, there is also evidence of productivity spillovers, particularly for informal firms (Chhair and Newman 2014), suggesting that such knowledge spillovers may be more beneficial to informal firms who are likely to have more to learn from formal firms than the other way around (Overman and Venables 2005). In Ethiopia, Siba et al. (2012) find that agglomerating firms have higher productivity, but only if they produce products similar to other firms in the cluster.

Given that there are potentially significant benefits from agglomeration it is not surprising that firms tend to cluster beyond the level that we would expect due to urbanization. In Viet Nam, for example, Howard et al. (2011) use the tools of network analysis to show that manufacturing enterprises are in fact highly spatially concentrated and that this clustering was not driven by institutional factors such as zoning or location restrictions on firms. They find significant clustering outside of Viet Nam's well known SEZs and that localization economies matter more than urbanization.

\footnotetext{
${ }^{2}$ See Combes and Gobillon (2015) for a thorough overview of the empirical challenges in identifying agglomeration economies.
} 
Because there are potentially significant benefits from agglomeration, a case can be made for policies to encourage the formation of industrial clusters. Agglomeration poses a classic collective action problem. There is little incentive for an individual firm to move to a new greenfield industrial location, unless a critical mass of similar firms can be encouraged to move at the same time. SEZs have the potential to foster industrial clusters by concentrating investments in highquality institutions, social services, and infrastructure in a limited geographical area. A common feature of SEZs is that they offer tax breaks, subsidies and usually some form of free trade arrangement combined with conditions on firms in the zone to export. If successful this will lead to investment, employment creation, and given the discussion in section 2, productivity spillovers. SEZs have played a key role in East Asia's industrialization with examples of hugely successful SEZs in China, Korea, Singapore and Taiwan.

\subsection{SEZs as instruments of industrial policy}

SEZs are often a key component of a broader industrialization strategy targeted at attracting FDI and promoting exports, but the literature on the role of SEZs, from both a theoretical and an empirical perspective, is relatively sparse. Early theoretical work focused on the role of SEZs in trade liberalization. Hamada (1974) was among the first to present a theoretical framework for analysing the economic implications of a duty-free zone. In his model duties are exempted in order to attract foreign investments. Using the standard Heckscher-Ohlin framework he concludes that SEZs are a second-best policy instrument to the optimal policy of trade liberalization and should only be deployed in highly distorted environments in which there is anti-export bias. Later work by Miyagiwa (1986) shows that introducing an SEZ in a high tariff economy can increase national welfare, but that broad-based tariff liberalization is preferable. Until quite recently, this view pervaded operational policy in the World Bank, which regarded the use of SEZs as an inferior substitute for general trade liberalization (Page 2012).

To some extent these early trade policy focused analyses miss the point. Where they have succeeded, SEZs provide a setting that can encourage the formation of industrial clusters by making some industrial locations more attractive to investors, including foreign investors. This in turn can support a more broad-based industrialization strategy. Schrank (2001) for example defines the life-cycle of a successful EPZ as consisting of three phases: i) luring foreign investors; ii) demonstrating the feasibility of international competition; and iii) drawing local manufacturers into world markets. Johansson and Nilsson (1997) use a gravity model to show that EPZs have increased total exports of several developing countries. Madani (1999) highlights the long-term dynamic role that SEZs can play in the development process, if well-managed and used as part of a national reform programme. Farole (2011) takes a similar view.

The extent to which SEZs succeed as an instrument for longer-term industrial development critically depends on the nature of the links between the zone and the domestic economy. This in turn depends on the capabilities of domestic firms. Schrank (2001) compares the experiences of South Korea and the Dominican Republic, both of which introduced EPZs at the time when their per capita GDP was identical. South Korea used 'a process of constant integration' to transform its EPZs into major markets for locally manufactured capital and intermediate goods. The Dominican Republic was unable to follow this pattern; export manufacturers in the zones purchased almost nothing from local suppliers, and vertical integration and linkages with the rest of the economy remained weak. The Industrial Linkages Program, an effort to encourage greater integration between local firms and the EPZs in the late 80s and early 90s, failed largely due to the 
tariff regime. Many upstream sectors simply did not exist and those that did failed to meet world standards in price and quality.

Schrank (2001) found similar outcomes in Mexico, where the Border Industrialization Program (BIP) created a series of free trade areas along the US frontier in 1965. In 1975 the government extended the BIP's incentives to export-orientated firms located beyond the frontier. About the same time, the overhaul of the North American manufacturing economy carried a steady flow of technologically sophisticated investment south of the border. While exports from the frontier remained dependent on foreign inputs, BIP counterparts in the interior purchased a greater proportion of their inputs at home. All three cases demonstrate the necessity of setting SEZ programmes within the context of a larger industrial policy framework.

\subsection{Africa's Track Record of SEZs}

Most African countries are relative latecomers to the promotion of SEZs. Many national EPZ programmes began only in the late 1990s or early 2000s, often in response to the US Africa Growth and Opportunities Act (AGOA) and the Multi-Fiber Arrangement (MFA). Many African SEZs experienced rapid growth between 2000 and 2004, but when the MFA expired in 2005 slower growth (or even decline) set in. Anecdotal evidence suggests that, in many countries-such as Malawi, Mali, Nigeria, Senegal, and Tanzania_zones are struggling. Globally SEZs rarely experience rapid growth in their first 5-10 years of operation, and it may be too early to fully judge their success in Africa, but (with the possible exceptions of Ethiopia and Ghana) African zones seem to be failing to shift to the more rapid growth path that would be expected after 5-10 years of operation.

Farole (2011) provides the most comprehensive review available of the evidence (both case study and based on firm-level surveys) on the performance of SEZs in Africa. The success of SEZ programmes is generally measured by the extent to which they attract FDI, increase exports, create jobs and lead to productivity spillovers. Farole finds in general that African zones under-perform with respect to each of these measures. FDI into African SEZs is low, relative to non-African zones, although FDI into SEZs is a relatively high proportion of the total national figure. ${ }^{3}$ This suggests either: (i) that the failure of African SEZs to attract investment may be due to a poor overall investment climate or (ii) that the zones themselves fail to offset the worst aspects of the national investment climate.

Exports tell a similar story; manufactured exports from African EPZs are small in absolute terms and relative to more dynamic SEZs elsewhere. Farole notes that while Viet Nam and Bangladesh experienced dramatic structural shifts in manufacturing output and exports following the establishment of SEZs, the same cannot be said for African countries. Although the zones in Ghana performed well in terms of exports, partly as a result of cocoa processing, firms in Kenya's and Tanzania's EPZs exported little (Farole 2011). As with the case of FDI, it is difficult to determine from the evidence available whether this lack of export dynamism reflects the poor performance of African manufactured exports more generally or a failure of exports from the zones in particular.

Given the lackluster performance of SEZs in Africa in terms of FDI and exports, it is not surprising that the absolute and relative contribution of African SEZs to employment is also limited (with the significant exception of Lesotho). Moreover, there is little evidence of linkages

\footnotetext{
${ }^{3}$ Ghana, he notes, is the exception.
} 
between firms in African SEZs and local firms. ${ }^{4}$ Often, SEZs have been put in place with little effort to support domestic investment into the zone or to promote links with firms outside the zone and as a result have become enclaves that are not connected to domestic value chains. A second channel for transmitting spillovers is the movement of workers and managers across firms, but Farole finds that African zones rely more heavily on foreign management than non-African SEZs. This means that the domestic economy misses out on those agglomeration economies that are a reflection of the transfer of capabilities.

\section{The changing landscape of SEZs in Africa}

While there are clear examples of successful 'bottom-up' clusters in Africa as highlighted in section 2, the experience thus far of SEZs has created justifiable skepticism about their use as a tool of industrial policy. Nevertheless, a number of countries in Africa for example Ethiopia, Ghana, Nigeria and Tanzania are giving SEZs another go. In this section we document information available online on mainly state financed SEZ programmes in SSA and the policies that are in place, or proposed, to promote them.

We rely exclusively on internet sources and so our overview does not capture all SEZ programmes in operation in SSA. We considered all 46 countries in SSA and found considerable heterogeneity across countries in the extent of information on SEZs that is available online. For countries where no information is available, for example, Ethiopia, it clearly does not mean that there are no SEZs in that country, rather there is no easily accessible information on them.

\subsection{SEZs in existence and incentives offered}

The full list of countries where we found information on SEZs are presented in Table 1. Also presented are the zones considered and the main incentives offered.

\footnotetext{
${ }^{4}$ In fact, local sourcing is problematic for SEZs worldwide, with the exception of larger markets like Korea and Indonesia.
} 
Table 1: SEZs currently in operation in sub-Saharan Africa

\begin{tabular}{|c|c|c|}
\hline $\begin{array}{l}\text { Countries with online information on } \\
\text { operational SEZs: }\end{array}$ & Zones (year established) & Main incentives offered \\
\hline Angola & $\begin{array}{l}\text { Luanda-Bengo ZEE (2009) } \\
\text { Activities: } 7 \text { industrial reservations, } 6 \text { agricultural } \\
\text { reservations, } 8 \text { mining reservations }\end{array}$ & Infrastructure and services \\
\hline Benin & $\begin{array}{l}\text { Free Processing Zone of Benin } \\
\text { Activities: Biotechnology, IT \& Communications }\end{array}$ & No information \\
\hline Cameroon & Industrial Free Zones (1990) & $\begin{array}{l}\text { 10-year exemption from taxes } \\
\text { Flat tax of } 15 \% \text { on corporate profits from the } 11 \text { th year onwards } \\
\text { Tax free repatriation of all funds earned and invested in Cameroon } \\
\text { Exemption from foreign exchange regulations }\end{array}$ \\
\hline Cote d'Ivoire & Free Zone Village of IT and Biotechnology (2008) & $\begin{array}{l}\text { Exemption from income tax for the first } 5 \text { years } \\
1 \% \text { income tax on revenue from the } 6 \text { th year onwards, with possible } \\
\text { tax rebate } \\
0 \% \text { Custom duties and VAT } \\
\text { Free transfer of funds on salaries and dividends } \\
\text { Long term visas and work permits for workers \& families limitation on } \\
\text { local and foreign }\end{array}$ \\
\hline Democratic Republic of Congo & $\begin{array}{l}\text { Malaku SEZ (2012) } \\
\text { Activities: Agribusiness, Building Materials, Packaging, } \\
\text { Metallurgical transformation }\end{array}$ & Tax and cusoms incentives \\
\hline Djibouti & $\begin{array}{l}\text { Djibouti Free Zone (2004) } \\
\text { DAM Commercial Free Zone (2013) }\end{array}$ & $\begin{array}{l}100 \% \text { foreign ownership allowed } \\
\text { Full exemption from direct \& indirect taxes } \\
100 \% \text { repatriation of capital \& profits } \\
\text { No currency restrictions } \\
\text { Flexible recruitment laws }\end{array}$ \\
\hline Eritrea & $\begin{array}{l}\text { Massawa Free Zone (2006) } \\
\text { Activities: Construction materials, Agro-processing, } \\
\text { Batteries }\end{array}$ & $\begin{array}{l}\text { No taxes on income, profits or dividends } \\
\text { No customs duties on imports } \\
\text { No currency convertibility restrictions } \\
\text { No minimum investment } \\
100 \% \text { foreign ownership allowed } \\
100 \% \text { repatriation on profits and capital }\end{array}$ \\
\hline Gabon & $\begin{array}{l}\text { Nkok SEZ (2010) } \\
\text { Activities: Timber activities, Chemicals, Agro-industry, } \\
\text { Construction materials, Metallurgy } \\
\text { Mandji Tax-Free Zone (2014) } \\
\text { Activities: Oil \& Gas }\end{array}$ & $\begin{array}{l}\text { Zero tax on dividends and land properties } \\
\text { Zero tax on income in the first } 10 \text { years and } 10 \% \text { for the next } 5 \text { years } \\
100 \% \text { repatriation of funds allowed } \\
100 \% \text { exemption on income tax, corporate tax \& capital gains tax } \\
100 \% \text { foreign ownership permitted }\end{array}$ \\
\hline
\end{tabular}




\begin{tabular}{|c|c|c|}
\hline & & $\begin{array}{l}\text { No custom duty on import of plant and machinery or spare parts for } \\
\text { industries } \\
\text { Electricity at subsidised rates for SEZ based industry }\end{array}$ \\
\hline The Gambia & $\begin{array}{l}\text { Export Processing Zones (2010) } \\
\text { July } 22 \text { Business Park (2005) } \\
\text { Activities: Garments, Diapers \& Tissue manufacturing }\end{array}$ & $\begin{array}{l}\text { Exemption from: import or excise duty and sales tax on goods, import } \\
\text { duty on capital equipment, corporate and turnover tax, withholding tax } \\
\text { on dividends and municipal tax }\end{array}$ \\
\hline Ghana & $\begin{array}{l}\text { Tema EPZ } \\
\text { Activities: Textiles \& Garments } \\
\text { Ashanti Technology Park } \\
\text { ICT Cyber Village } \\
\text { Cocoa Processing, Light Industrial Manufacturing, } \\
\text { Heavy Industrial Manufacturing, Warehousing \& } \\
\text { Logistics Services, Social Services Centre, Bio- } \\
\text { technology development } \\
\text { Sekondi EPZ } \\
\text { Activities: Mineral Processing } \\
\text { Shama EPZ } \\
\text { Activities: Petrochemical activities }\end{array}$ & $\begin{array}{l}100 \% \text { exemption from payment of direct \& indirect duties and levies } \\
\text { on all imports for production and exports from free zones } \\
100 \% \text { exemption from payment of income tax on profits for } 10 \text { years } \\
\text { and shall not exceed } 8 \% \text { thereafter } \\
\text { Total exemption from payment of withholding taxes from dividends } \\
\text { arising out of free zone investments } \\
\text { Relief from double taxation for foreign investors and employees } \\
\text { No import licensing requirements } \\
\text { Minima customs formalities } \\
100 \% \text { ownership of shares by any investors is allowed } \\
\text { No restrictions on repatriation of dividends or net profits, payments for } \\
\text { foreign loan servicing, payments of fees and charges for technology } \\
\text { transfer agreements, remittance of proceeds from sale of any interest in } \\
\text { a free zone investment } \\
\text { Free Zone investors are permitted to operate foreign currency account } \\
\text { with banks in Ghana }\end{array}$ \\
\hline Kenya & $\begin{array}{l}\text { EPZs (52 in total) (1990) } \\
\text { Activities: Textile \& apparels, Business Process } \\
\text { Outsourcing, IT Enabled Services } \\
\text { Athi River EPZ } \\
\text { Activities: Garments, Cotton yarn, Pharmaceuticals, } \\
\text { Gemstones, Computers, Food processing, Tanning } \\
\text { products, Electrical goods, Construction \& lease of } \\
\text { industrial buildings } \\
\text { Sameer Industrial Park EPZ (1990) } \\
\text { Activities: Garments \& Apparel, Agro-processing, Call } \\
\text { centre, Relief supplies, Gemstones, Macadamia } \\
\text { The following zones specialize in garments: } \\
\text { Kipevu Zone (1996), Balaji EPZ (2001), Mazeras } \\
\text { Kenya EPZ (2002), Pwani Industrial Park EPZ (2000), } \\
\text { Ammar EPZ (1993), Mvita Industrial Park EPZ } \\
\text { (2004) }\end{array}$ & $\begin{array}{l}\text { 10-year tax holiday } \\
\text { Duty, Stamp Duty \& VAT Exemption } \\
\text { Exemption from withholding tax for } 10 \text { years } \\
25 \% \text { corporate tax for } 10 \text { years following the first } 10 \text { years } \\
100 \% \text { investment deduction on initial investment applied over } 20 \text { years }\end{array}$ \\
\hline
\end{tabular}


Free zones are exempted from corporate tax for up to 15 years

Free regime companies operating in the industrial transformation and intensive production are exempted of corporate tax for 5 years

Free regime companies operating in the service sector are exempted of corporate tax for 2 years

The income tax for expatriates working for free zone companies cannot exceed $30 \%$

No VAT on imports realized by free zones and free regime companies

\begin{tabular}{|c|c|c|}
\hline Malawi & EPZ (1995) & $\begin{array}{l}\text { Exemption of corporate income tax } \\
\text { No withholding tax on dividends } \\
\text { No duty on capital equipment, machinery and raw materials } \\
0 \% \text { VAT }\end{array}$ \\
\hline Mauritius & $\begin{array}{l}\text { Mauritius Free Port (1992) } \\
\text { Sameer Industrial Park EPZ (1990) } \\
\text { Activities: Garments \& Apparel, Agro-processing, Call } \\
\text { centre, Relief supplies, Gemstones, Macadamia, } \\
\text { Warehousing and storage and breaking bulk, Ship } \\
\text { building, repair and maintenance, Storage, } \\
\text { maintenance and repair of empty containers, Export } \\
\text { \& re-export oriented airport and seaport based } \\
\text { activities, Labeling, packing and repackaging, Light } \\
\text { assembly and minor processing, Quality control and } \\
\text { inspection services, Sorting, grading, cleaning and } \\
\text { mixing, Freight forwarding services, Seafood hub }\end{array}$ & $\begin{array}{l}0 \% \text { corporate tax for trading activities } \\
15 \% \text { tax for processing activities } \\
\text { Reduced port handling charges for all goods destined for re-export } \\
100 \% \text { foreign ownership allowed } \\
\text { Access to local market- } 50 \% \text { of re-export value } \\
\text { Preferential market access } \\
\text { Exemption from customs duties on all goods imported into the } \\
\text { Freeport zones } \\
\text { Free repatriation of profits. }\end{array}$ \\
\hline Mozambique & $\begin{array}{l}\text { Nacala SEZ (2007) } \\
\text { Activities: Textiles \& confection, Leather \& Tannery, } \\
\text { Construction, Production of construction materials, } \\
\text { cement and iron, Ceramics industry, Assembly of } \\
\text { machines and production lines } \\
\text { Mocuba SEZ \& IFZ } \\
\text { Activities: Commercial agriculture, aquaculture and } \\
\text { agro-processing, Mineral Processing, Lumber } \\
\text { industry, Livestock and Dairy Products, } \\
\text { Manufacturing, Textile industry } \\
\text { Beluluane IFZ (1998) Servicing MOZAL, Light } \\
\text { Activities: Companies sem, } \\
\text { manufacturing and production, Heavy manufacturing, } \\
\text { Downstream aluminum conversion and processing, } \\
\text { Service industries, Packaging and labeling, }\end{array}$ & $\begin{array}{l}\text { Income tax for SEZ Developers: } \\
\text {-Income tax exemption in the first } 5 \text { fiscal years } \\
-50 \% \text { reduction in the rate of income tax from } 6 \text { th to } 10 \text { th fiscal years } \\
-25 \% \text { reduction in the rate of income tax for the remaining life of the } \\
\text { project } \\
\text { Income tax for SEZ enterprises: } \\
\text {-Income tax exemption in the first } 3 \text { fiscal years } \\
-50 \% \text { reduction in the rate of income tax from the } 4 \text { th to the } 10 \text { th tax } \\
\text { year } \\
\text {-Income tax for SEZ Service Enterprise: } \\
-50 \% \text { reduction in the rate of income tax for a period of } 5 \text { fiscal years } \\
\text { Industrial Free Zone Developer and Enterprises: } \\
\text {-Income tax exemption in the first } 10 \text { fiscal years } \\
-50 \% \text { reduction in the rate of income tax from the } 11 \text { th to the } 15 \text { th tax } \\
\text { year }\end{array}$ \\
\hline
\end{tabular}




\begin{tabular}{|c|c|c|}
\hline & $\begin{array}{l}\text { Manufacturing primarily for export, Training } \\
\text { providers, Industrial linkage companies, Profession } \\
\text { e.g. health, legal, business services, Stockpiling raw } \\
\text { materials, Forwarding manufactured goods, Value } \\
\text { adding industries } \\
\text { Manga-Mungassa SEZ (2012) } \\
\text { Crusse \& Jamali Integrate Tourism Development } \\
\text { Zone (2013) } \\
\text { Activities: Tourism \& Entertainment }\end{array}$ & $\begin{array}{l}-25 \% \text { reduction in the rate of income tax for the remaining life of the } \\
\text { project } \\
\text { Isolated Free Zone Enterprises: } \\
- \text { Income tax exemption in the first } 10 \text { tax years } \\
-50 \% \text { reduction in the rate of income tax from the } 6 \text { th to } 10 \text { th fiscal } \\
\text { years } \\
-25 \% \text { reduction in the rate of income tax for the remaining life of the } \\
\text { project }\end{array}$ \\
\hline Namibia & $\begin{array}{l}\text { EPZs (1996) } \\
\text { Activities: Minerals beneficiation, Diamond cutting and } \\
\text { polishing operations } \\
\text { Walvis Bay EPZ } \\
\text { Activities: Textile and garment industries, } \\
\text { Manufacturing plastic pallets and products, } \\
\text { Automotive parts for VW and Audi vehicles, Fishing } \\
\text { related accessories, Diamond cutting and polishing }\end{array}$ & $\begin{array}{l}\text { Exemption from corporate income tax, customs duties and VAT on } \\
\text { machinery, equipment and raw materials }(10 \% \text { withholding tax on } \\
\text { dividends and personal income tax are still payable } \\
\text { EPZ enterprises are allowed to hold foreign currency accounts at } \\
\text { commercial banks and repatriate capital and profits. } \\
\text { The incentives offered are applicable for an indefinite period or for the } \\
\text { lifetime of the approved project. }\end{array}$ \\
\hline Nigeria & $\begin{array}{l}\text { Calabar FTZ (1992) } \\
\text { Activities: Manufacturing, Oil \& Gas, Logistic Services } \\
\text { Kano FTZ (1998) } \\
\text { Activities: Manufacturing, Logistics Services, } \\
\text { Warehousing } \\
\text { Tinapa Free Zone (2004) } \\
\text { Activities: Manufacturing, Trade, Tourism \& Resort } \\
\text { Snake Island IFZ (2005) } \\
\text { Activities: Steel Fabrication, Oil \& Gas, Sea Port } \\
\text { Maigatari Border Free Zone (2000) } \\
\text { Activities: Manufacturing \& Warehousing } \\
\text { Ladol Logistics Free Zone (2006) } \\
\text { Activities: Oil \& Gas Fabrication, Oil \& Gas Vessels, } \\
\text { Logistics } \\
\text { Airline Services EPZ (2003) } \\
\text { Activities: Food Processing \& Packaging } \\
\text { ALSCON EPZ (2004) } \\
\text { Activities: Manufacturing } \\
\text { Sebore Farms EPZ (2001) } \\
\text { Activities: Manufacturing, Oil \& Gas, Petrochemical } \\
\text { Ogun Guagdong FTZ (2008) } \\
\text { Activities: Manufacturing }\end{array}$ & $\begin{array}{l}\text { Complete tax holiday for all Federal, State and Local Government taxes, } \\
\text { rates, custom duties and levies } \\
\text { One stop approval for all permits, operating licenses and incorporation } \\
\text { papers } \\
\text { Duty-free, tax-free import of raw materials for goods destined for re- } \\
\text { export } \\
\text { Duty free introduction of capital goods, consumer goods, components, } \\
\text { machinery, equipment and furniture } \\
\text { Permission to sell } 100 \% \text { of manufactured, assembled or imported } \\
\text { goods into the domestic Nigerian market } \\
\text { When selling into the domestic market, the amount of import duty on } \\
\text { goods manufactured in the free zones is calculated on the basis of the } \\
\text { e value of the raw material or components used in assembly, not the } \\
\text { finished product. } \\
100 \% \text { foreign ownership of investments } \\
100 \% \text { repatriation of capital, profits and dividends } \\
\text { Waiver of all import and export licenses } \\
\text { Waiver on all expatriate quotas for companies operating in the zones } \\
\text { - Prohibition of strikes and lockouts } \\
\text { - Rent free land during the first } 6 \text { months of construction. }\end{array}$ \\
\hline
\end{tabular}




\begin{tabular}{|c|c|c|}
\hline & $\begin{array}{l}\text { Lekki Free Zone (2008) } \\
\text { Activities: Manufacturing, Logistics } \\
\text { Abuja Tech Village Free Zone (2007) } \\
\text { Activities: Science \& Technology, Ibom Science \& Tech } \\
\text { Free Zone (2006) } \\
\text { Activities: Science \& Technology } \\
\text { Lagos FTZ (2002) } \\
\text { Activities: Manufacturing, Oil \& Gas, Petrochemical } \\
\text { Olokola FTZ (2004) } \\
\text { Activities: Oil \& Gas, Manufacturing } \\
\text { Living Spring Free Zone (2006) } \\
\text { Activities: Manufacturing, Warehousing, Trading } \\
\text { Brass LNG Free Zone (2007) } \\
\text { Activities: Liquefied Natural Gas }\end{array}$ & $\begin{array}{l}\text { - All new industrial undertakings including foreign companies, as well } \\
\text { as individuals operating in an EPZ, are allowed full tax holidays for } 3 \\
\text { consecutive years. }\end{array}$ \\
\hline Rwanda & $\begin{array}{l}\text { Kigali SEZ (2011) } \\
\text { Activities: Heavy \& light manufacturing industries, } \\
\text { Large scale users, industrial plants, Commercial } \\
\text { wholesalers, Chemical, pharmacy and plastics, } \\
\text { Warehousing, Tourism \& Service industry, } \\
\text { ICT Logistics }\end{array}$ & Imported goods are free from customs duties \\
\hline Senegal & $\begin{array}{l}\text { Dakar Integrated SEZ (2007) } \\
\text { Activities: Industrial, Offices, Tourist resorts, } \\
\text { Commerce \& Services }\end{array}$ & $\begin{array}{l}100 \% \text { foreign ownership } \\
\text { One single authority for all licenses, permits and authorisation } \\
\text { Availability of serviced land and pre-built units for industrial, } \\
\text { commercial, logistics and services uses } \\
\text { A relaxed foreign labour regime } \\
\text { Freedom to obtain foreign currency } \\
\text { Protection of property rights } \\
\text { Exemption from customs duties and taxes on all imported goods } \\
\text { Exemption from payment of any direct income taxes } \\
\text { A flat } 2 \% \text { rate tax applicable on sales on local market } \\
\text { Full repatriation of profits and capital }\end{array}$ \\
\hline Sierra Leone & $\begin{array}{l}\text { First Step (2012) } \\
\text { Activities: Agricultural goods, Apparel Manufacturing, } \\
\text { Mineral Resources, Marine Resources, Export } \\
\text { Processing }\end{array}$ & $\begin{array}{l}\text { Duty free status on all imported goods } \\
\text { Duty free status on all goods exported } \\
\text { Corporate tax holiday for the first } 3 \text { years }\end{array}$ \\
\hline South Africa & $\begin{array}{l}\text { Coega IDZ (1999) } \\
\text { Activities: Agro-processing, Automotive, Business } \\
\text { Process Outsourcing, Chemicals, Energy, Logistics, } \\
\text { Manufacturing, Metals, Textiles }\end{array}$ & $\begin{array}{l}\text { For IFZs: } \\
\text { Duty free import of production related materials } \\
\text { Zero VAT on materials sourced from South Africa }\end{array}$ \\
\hline
\end{tabular}




\begin{tabular}{|c|c|c|}
\hline & $\begin{array}{l}\text { East London IDZ (2003) } \\
\text { Activities: Automotive, Agro-processing, } \\
\text { Pharmaceuticals, ICT \& BPO, Renewable Energy, } \\
\text { Logistics, Aqua-culture, General manufacturing' } \\
\text { Saldanha Bay IDZ (2013) } \\
\text { Activities: Oil \& Gas, Marine engineering } \\
\text { Richards Bay IDZ } \\
\text { Activities: Agro-processing, Metals beneficiation } \\
\text { Dube Trade Port IDZ (2014) } \\
\text { Activities: Aerospace and aviation linked } \\
\text { manufacturing, Agriculture and agro-processing, } \\
\text { Electronics manufacturing and assembly, Medical and } \\
\text { pharmaceutical production and distribution, Clothing } \\
\text { \& textiles }\end{array}$ & $\begin{array}{l}\text { Right to sell in South Africa upon payment of normal import duties on } \\
\text { finished goods } \\
\text { For SEZs: } \\
\text { Reduction in corporate tax from } 28 \% \text { to } 15 \% \\
\text { Dedicated in-house Customs Controlled Area that expedites clearing } \\
\text { Duty free in imports for production related raw materials and } \\
\text { machinery } \\
\text { VAT exemptions under specific conditions for supplies procured in } \\
\text { South Africa } \\
\text { Employment tax incentive-businesses may be eligible for tax relief } \\
\text { including the employment tax incentive subject to requirements } \\
\text { Accelerate depreciation allowance on capital equipment and assets. }\end{array}$ \\
\hline Sudan & $\begin{array}{l}\text { Suakin Free Zone (2000) } \\
\text { Activities: } 41 \% \text { industrial, } 15 \% \text { commercial, } 44 \% \\
\text { service } \\
\text { Alijaily Free Zone (2009) } \\
\text { Activities: Industrial investment and assembly } \\
\text { industries, Supporting services, logistic centres and } \\
\text { distribution services, Food industries trade centres, } \\
\text { Light transformational industries, Packing and } \\
\text { packaging requirement industry, Petrochemicals and } \\
\text { plastic products industry, Financial and consultancy } \\
\text { services }\end{array}$ & $\begin{array}{l}\text { Exemption from tax on profits for a } 15 \text { year period, renewable by } \\
\text { decision of the minister responsible } \\
\text { Salaries of expatriates working in projects within the free zones are } \\
\text { exempted from personal income tax } \\
\text { Exemption of products imported into the free zone or exported abroad } \\
\text { from all customs fees and taxes except services fees } \\
\text { Real estate establishment inside the zones are exempted from all taxes } \\
\text { and fees } \\
\text { Invested capital and profits are transferable from Sudan to abroad } \\
\text { through any licensed bank operating in the free zone } \\
\text { Exemption from customs fees } \\
\text { Money invested in the free zones may not be frozen or confiscated }\end{array}$ \\
\hline Tanzania & $\begin{array}{l}\text { EPZs and SEZs (2002): Millennium Business Park; } \\
\text { Hifadhi EPZ; Kisongo EPZ; Kamal Industrial Estate } \\
\text { EPZ; BWM SEZ; Global Industrial Park. } \\
\text { Activities: Textiles \& Garments, Agro-processing, } \\
\text { Leather processing and manufacture of leather } \\
\text { products, Fish processing, Wood products, } \\
\text { Agricultural \& Agro-Industrial } \\
\text { Industrial, Tourism, Commercial } \\
\text { Forestry, ICT, Banking \& Financial centre }\end{array}$ & $\begin{array}{l}\text { For EPZs: } \\
\text { Exemption from payment of taxes and duties for capital used in } \\
\text { development } \\
\text { Exemption from corporate tax for } 10 \text { years initially, thereafter } \\
\text { corporate tax shall be charged at a rate specified by the Income Tax Act } \\
\text { Exemption from withholding tax on rent, dividends and interest } \\
\text { Investments in SEZs offer similar incentives but does not include a 10- } \\
\text { year exemption from corporate taxes. }\end{array}$ \\
\hline Togo & $\begin{array}{l}\text { EPZs (1989) } \\
\text { Activities: Food industry and agro-industry and } \\
\text { horticulture, Wood industry, metallic engineering } \\
\text { industry and plastic industry, Clothing industry, }\end{array}$ & $\begin{array}{l}\text { Exemption from all customs duties and taxes on capital and production } \\
\text { materials, as well as exporting goods manufacture within the free zone. } \\
\text { Also, a } 50 \% \text { reduction in the same duties and taxes on commercial } \\
\text { vehicles. }\end{array}$ \\
\hline
\end{tabular}


synthetic hairs, leathercraft, pharmaceutic industry, cosmetic industry, Textile, Light engineering products and electronics, Jewellery, diamonds polishing, Building materials industry

Stationery 10-year exemption from VAT

Stabilisation of corporate duty at the reduced rate of:

$-5 \%$ duty on taxable profit during the first 5 years of operation

$-10 \%$ taxable profit from the 6 th year to the 10 th year

$-15 \%$ taxable profit from the 11 th to the 20 th year

Ordinary law shall apply as from the 21 st year onwards (regular rate of $30 \%)$

Reduced flat rate of $2 \%$ payroll tax for the lifetime of the company (as opposed to the $7 \%$ regular rate)

Reduction in business licence tax:

$-5 \%$ tax from the 2 nd to the 5 th year of operation

$-10 \%$ tax from the 6 th to the 10 th year

$-15 \%$ tax from the 11 th to the 20 th year

-Ordinary law shall apply as from the 21 st year onwards

Reduction in land tax:

$-5 \%$ tax from the 2 nd to the 5 th year

$-10 \%$ tax from the 6 th to the 10 th year

$-15 \%$ tax from the 11 th to the 20 th year

Ordinary law shall apply as from the 21st year onwards
Exemption from taxes and duties on all imported raw materials and intermediate goods and capital for exclusive use in the development of production output

Unrestricted remittance of profit after tax

Tax holiday for 10 years on finished consumer and capital goods

$100 \%$ exemption from tax on income from agro-processing

$100 \%$ exemption on income derived from the operation of aircrafts in domestic and international traffic or the leasing of aircraft

Exemption on plant and machinery used in the free zones for 5 years and 1 day from Customs duty upon disposal.

Exemption from all taxes, levies and rates on exports from the free zones namely excise duty and Customs taxes;

$100 \%$ exemption from tax on income of a person offering Technical Assistance under a Technical Assistance Agreement;

Exemption from import duties and taxes on all goods entering a free port zone;

VAT exemption on supply of selected services e.g. medical services, social welfare services, power generated by solar;

Exemption of Withholding Tax on petroleum, petroleum products, plant and machinery, human or animal drugs and supply/importation of raw materials. 


\begin{tabular}{|c|c|c|}
\hline & $\begin{array}{l}\text { Nakaseke SEZ (2015) } \\
\text { Activities: Agribusiness products }\end{array}$ & Duty Free Status \\
\hline Zambia & $\begin{array}{l}\text { Chambishi MFEZ (2007/2008) } \\
\text { Activities: Copper smelting, Manufacture of household } \\
\text { appliances, Manufacture of bars, wires, electric cables } \\
\text { and motor parts, Agro-processing, } \\
\text { Lusaka East MFEZ (2009) } \\
\text { Activities: Light manufacturing activities, Provision of } \\
\text { services such as conference facilities and hotel } \\
\text { accommodation } \\
\text { Lusaka South MFEZ (2012) } \\
\text { Sub-Saharan Gemstone Exchange Industrial Park } \\
\text { Activities: Warehousing \& Storage, Light Industry, Oil } \\
\text { refinery, Residential, Gemstone processing } \\
\text { Roma Industrial Park (2011) } \\
\text { Activities: Light industries, Retail parks, Office Park, } \\
\text { Warehousing }\end{array}$ & $\begin{array}{l}\text { MFEZ: } \\
\text { Profits on tax: } \\
-0 \% \text { for the first } 5 \text {-years profits are made. } \\
-50 \% \text { of profits taxed for years } 6 \text { to } 8 \\
-75 \% \text { of profits taxed for years } 9 \text { and } 10 \\
0 \% \text { tax rate on dividends of companies operating under the MFEZ for } \\
\text { a period of } 5 \text { years from the year of first declaration of dividends } \\
0 \% \text { import duty rate on raw materials, capital goods, machinery } \\
\text { including trucks and specialised vehicles for } 5 \text { years. } \\
\text { Deferment of VAT on machinery and equipment including trucks and } \\
\text { specialised motor vehicles imported for investment in MFEZ. }\end{array}$ \\
\hline Zimbabwe & $\begin{array}{l}\text { EPZs (1996) } \\
\text { Activities: Mining, Agro-processing }\end{array}$ & $\begin{array}{l}5 \text {-year tax holiday. Following the initial } 5 \text { year period, tax is paid at a } \\
\text { rate of } 25 \% \text {, rather than the normal rate of } 35 \% \text {. } \\
\text { Duty free importation of raw materials and capital equipment for use } \\
\text { in the EPZ } \\
\text { No tax liability from capital gains arising from the sale of capital } \\
\text { invested } \\
\text { Mining sectors investors in EPZs: } \\
\text { Reduced corporation tax of } 20 \% \\
\text { Import duty exemption on imported capital goods. }\end{array}$ \\
\hline
\end{tabular}

Note: The following countries were considered but no information on SEZs for these locations could be found online: Botswana, Burkina Faso, Burundi, Cape Verde, Central African Republic, Chad, Congo (Brazzaville), Equatorial Guinea, Ethiopia, Guinea, Guinea Bissau, Lesotho, Liberia, Mali , Niger, Sao Tome and Principe, Seychelles, Somalia and Swaziland.

Sources: See Appendix A. 
It is clear from this, albeit incomplete, inventory that a significant number of SEZs have been established across SSA over the last three decades. The earliest established zones in our sample were a number of EPZs set up in Togo in 1989 covering the food and agri-business, wood, metal engineering and plastic, clothing and textile, pharmaceuticals and other light manufacturing. Other early movers include Cameroon, Kenya, Malawi, Mauritius, Namibia, Nigeria and Zimbabwe, with a number of zones established in the early 1990s that remain in operation today. The majority of zones were established during the 2000s. Between 2000 and 2009, 38 zones were established in 14 countries. Sixteen zones were established in Nigeria during this decade and six in Tanzania. Between 2010 and 2016 an additional 16 zones were established. ${ }^{5}$ The real latecomers to SEZ development are Rwanda, Sierra Leone and Uganda where zones have only been established in recent years.

There is considerable variation across zones in the range of activities they are involved in. Most zones welcome investment from multiple sectors and in many cases these sectors are integrated along the supply chain in some way. For example, the Chambishi MFEZ in the Zambia hosts activities in copper smelting, the manufacture of household appliances and the manufacture of bars, wires, electric cables and motor parts. Many zones also offer supporting services for industry. For example, the Baluluane IFZ in Mozambique includes both light and heavy manufacturing coupled with supporting downstream industries (aluminum conversion and processing), packaging and labeling and other related services industries. These zones offer great potential both in terms of facilitating access to inputs and output markets for resident firms but also for agglomeration economies and productivity spillovers along the supply chain. Many zones offer supporting services such as call centres, business services, logistic services and conference facilities.

There are some zones that exclusively focus on a single activity. For example, Kenya is home to six EPZs exclusively focused on the garments sector. Garment only zones are also in operation in Tanzania. A number of zones exclusively dedicated to the oil and gas, minerals and other mining sectors also exist, most notably in Angola, Gabon, Ghana, Nigeria, South Africa and Zimbabwe.

Most countries have zones that include agriculture related sectors covering agri-business, agroprocessing, livestock and dairy products. Zones focused on high-end service sectors are less common. Some examples include the East London IDZ in South Africa and ITC and Biotechnology focused zones in Benin and Cote d'Ivoire.

SEZs offer a wide range of different incentives to investors. Tax reliefs are the most common incentives offered with all zones, with the exception of Angola offering some form of tax relief, deductions or exemptions. The zones in Angola only offer infrastructure and supporting services.

In some cases, very generous tax reliefs are offered. For example, zones in Eritrea offer no taxes on income, profits or dividends, and no customs duties on imports. The most common type of tax incentive offered is a zero or reduced rate of corporation or income tax for a number of years, increasing gradually thereafter. For example, zones in Kenya offer a tax amnesty for ten years, rising to 25 per cent corporate tax for the next ten years after. Similarly, zones in Zambia offer 0 per cent corporation tax for the first five years, 50 per cent of profits are taxed for years $6-8,75$ per cent of profits are taxed for years 9-10. In Zimbabwe, a 5-year tax holiday with a 25 per cent rate applied thereafter, rather than the normal rate of 35 per cent, is offered in zones. In Cote d'Ivoire, an exemption from income tax for the first five years is offered with a 1 per cent income tax rate on revenue from year six onwards with the possibility of a tax rebate. Zones in Sudan and

\footnotetext{
${ }^{5}$ We are missing information on the year of establishment of 11 zones in our sample.
} 
Uganda offer tax exemptions on construction of buildings. Duty free imports and exports are also common.

Other services offered by zones include employment services such as the provision of long-term visas, work permits and flexible recruitment laws. For example, in Senegal, one single authority for all licenses and permits is provided along with more relaxed laws in relation to the recruitment of foreign labour. In Nigeria, a guarantee that there will be no strikes or lockouts is provided in all 17 zones. Many zones also allow for 100 per cent foreign ownership of firms along with 100 per cent repatriation of profits.

Information on the effectiveness of the SEZs in terms of attracting investors is only available for 36 out of the 79 zones considered in Table 1. Information is unlikely to be available for unsuccessful SEZs and so we are dealing with a selected sample. With this in mind, we find that in 29 of the 36 cases where information is available, it appears that the zones are functioning well. For example, in Gabon, our online sources suggest that there are 80 investors located within zones from 18 different countries. There are eight firms in operation in the Nkok Zone in Gabon which was established in 2010 with a further 10 expected to be in operation by the end of 2016. The Djibouti Free Zone established in 2004 is home to 160 companies from 39 different nationalities. In South Africa 2,931 jobs are attributed to the 28 operational investors in their East London IDZ. In Togo, it is reported that 65 companies operate in SEZs directly employing 13,000 people accounting for approximately USD $\$ 500$ million of commercial activity. The Chambishi MFEZ in Zambia employs more than 5,600 people with a total investment outlay of more than USD $\$ 800$ million. In Zimbabwe, there are currently 183 designated companies located in EPZs. In Kenya the Athi River EPZ has 42 firms operating and is experiencing an increase in activity. By the end of 2016 this zone is expected to attract 100 textile investments. Five other zones in Kenya indicate that they are fully occupied.

As indicated, the SEZ success stories are easier to find than unsuccessful cases, and so the cases identified here are clearly a selected group. Nevertheless, within our sample of SEZs we do find some examples of less successful stories. For example, a significant delay in land allocation and local resistance eventually led to an investor removing their business from the Gambia. Lack of resources also hindered the effectiveness of the 'one stop approval service' offered by the board of the Ashanti Technology Park in Ghana. A scaling down of operations by some diamond cutting and polishing companies in the Walvis Bay EPZ in Namibia has resulted in a decrease in employment. In Kenya, the Kipevu SEZ remains undeveloped and the Sameer Industrial Park was scaled down due to a prolonged unfavorable business environment.

\subsection{SEZs planned or legislation in place}

Table 2 summarizes the information available online on SEZs that are currently planned or under development in SSA. We found information on only 13 countries. It should be noted that it is likely that there are many other countries with SEZs in the planning phase but with no information available. 


\begin{tabular}{|c|c|}
\hline Country & Planned SEZs \\
\hline Angola & $\begin{array}{l}\text { In October } 2015 \text { legislation was approved which establishes rules for the creation, } \\
\text { organization and functioning of SEZs. The incentives will include: } \\
\text { - Exemption on the payment of any customs duties on the export of manufactured goods } \\
\text { - Exemption on the payment of import duties on goods used as raw materials for a } 5 \text {-year } \\
\text { period } \\
\text { - Exemption on the payment of import duties on machinery and other equipment installed } \\
\text { in its units for a 10-year period }\end{array}$ \\
\hline Congo (Brazzaville) & $\begin{array}{l}\text { Four foreign trade zones located in Congo are in the planning process. Memoranda of } \\
\text { understanding were signed with the Governments of Mauritius and Singapore to solicit } \\
\text { technical expertise developing on these SEZs. } \\
\text { A Ministry to the Presidency in charge of SEZs began development in 2009. To date very } \\
\text { few companies have decided to locate in these SEZs. }\end{array}$ \\
\hline DRC & $\begin{array}{l}\text { A number of SEZs are planned over the coming years. They include } \\
\text { Kinshasa-Inga-Matadi-Banana } \\
\text { Ilebo-Tshikapa-Kananga-Mbuji Mayi } \\
\text { Kolwezi-Likasi-Lubumbshi-Sakania } \\
\text { Uvira-Bukavu-Goma-Beni-Bunia } \\
\text { Kisangani-Bumba-Mbandaka. }\end{array}$ \\
\hline Djibouti & $\begin{array}{l}\text { A number of new SEZs are planned over the coming years. They include: } \\
\text { Khor Ambado Free Zone } \\
\text { Jabanas Free Zone } \\
\text { UKAB Holdings Free Zone } \\
\text { Fabtec Industries Free Zone } \\
\text { Djibouti Free Trade Zone }\end{array}$ \\
\hline Gabon & $\begin{array}{l}\text { Franceville SEZ is currently being developed 650km southeast of Libreville. It aims to host } \\
\text { agricultural processing } \\
\text { An SEZ in Port Gentil focused on chemical engineering is being developed by Olam, a } \\
\text { Singapore-based } \\
\text { An SEZ for tourism is currently under consideration to be located at Nyoni, a coastal town } \\
\text { located about } 50 \mathrm{~km} \text { southwest of Libreville. }\end{array}$ \\
\hline & $\begin{array}{l}\text { As part of the Vision } 2030 \text { development agenda, the development of SEZs in Mombasa } \\
\left(2000 \mathrm{~km}^{2}\right) \text {, Lami }\left(700 \mathrm{~km}^{2}\right) \text { and Kisumu }\left(700 \mathrm{~km}^{2}\right) \text { have been approved. } \\
\text { Operations are expected to begin in Mombasa in } 2018 \text {. Activities will include wholesale \& } \\
\text { retail trading, breaking bulk, re-packaging logistics, warehousing and handling \& storage of } \\
\text { goods } \\
\text { The Kenyan Government is also in the process of converting EPZs into SEZs in order to } \\
\text { allow for a wider range of commercial ventures. } \\
\text { Incentives include a VAT exemption, a reduction in corporate tax from } 30 \% \text { to } 10 \% \text { for the } \\
\text { first } 10 \text { years and corporate tax of } 15 \% \text { for the } 11 \text { th to 20th years. } \\
\text { It was announced in } 2014 \text { that a FTZ in Mombasa would also be developed. }\end{array}$ \\
\hline
\end{tabular}

A special tax and custom regime is being created for the Zambezi Valley until 2025.

Mozambique

\begin{tabular}{|c|c|c|c|c|c|c|}
\hline \multirow{3}{*}{ Nigeria } & Zones & \multicolumn{3}{|c|}{ under } & & Construction: \\
\hline & Abuja & Tech & Village & Free & Zone & (2007) \\
\hline & Living & Spring & & & Zone & $(2006)$ \\
\hline
\end{tabular}




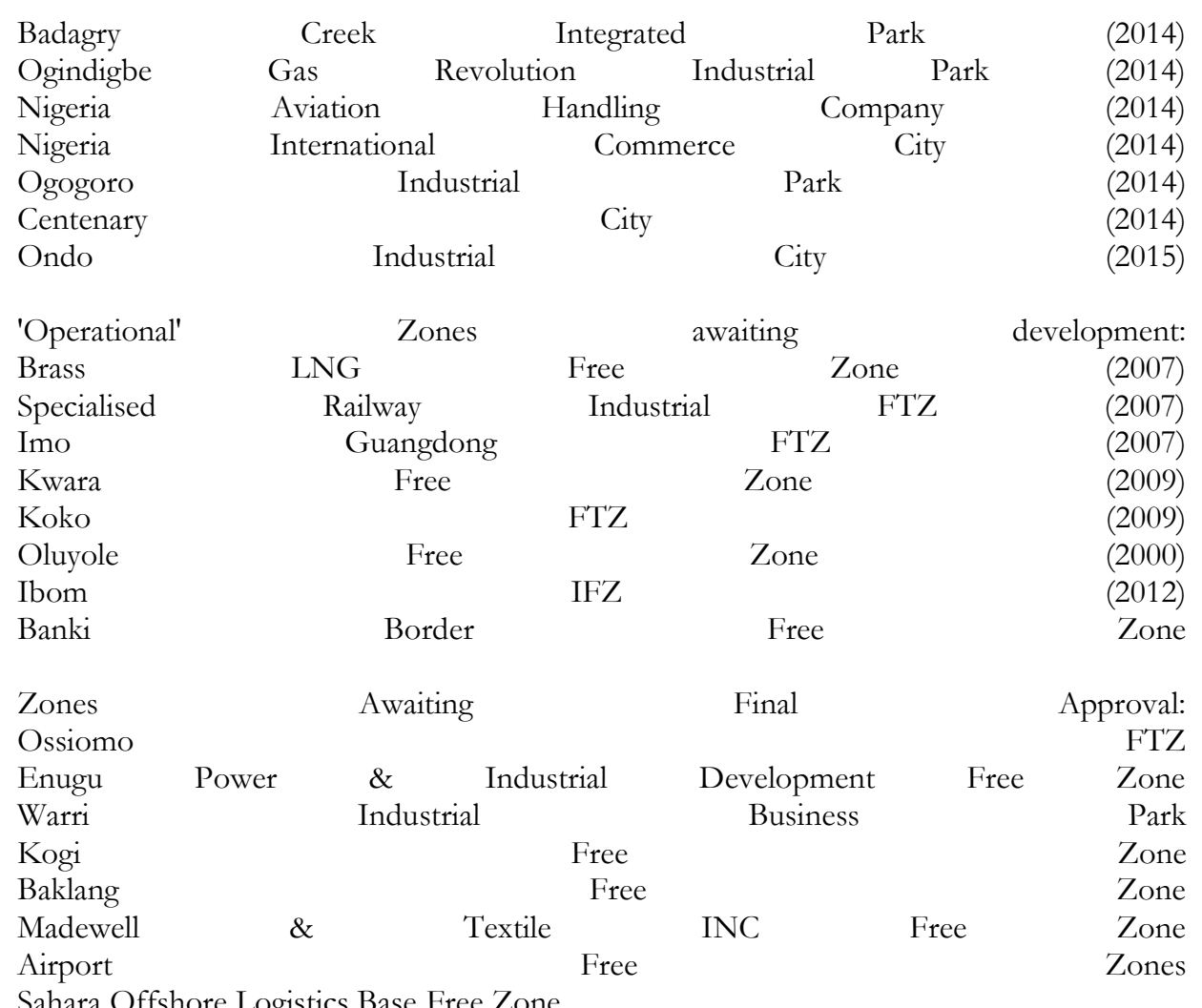

\begin{tabular}{ll}
\hline Senegal & Plans to develop additional SEZs in Ziguinchor in the southern Cassamance region. \\
& A number of new SEZs are planned over the coming years. They include: \\
Mthata & Harrismith \\
JHB & DTP \\
& Tubaste \\
& Musina \\
Skomazi & Upington \\
& Bojanala \\
& Atlantis \\
\hline & A new FTZ in Kosti near South Sudan is underway but progress has been slow. \\
& \\
Sudan & Two new SEZs are planned, Bagamoyo SEZ in Mbegani and the Kigoma SEZ. \\
\hline Tanzania & The Lumwana MFEZ is currently under development and will include the manufacture of \\
\hline Zambia & explosives, agro-processing, horticulture fisheries, and hotel accommodation \\
\hline
\end{tabular}

Sources: See Appendix A.

In Kenya, as part of the Vision 2030 development agenda a number of SEZs have been proposed and are expected to be operational by 2018. They will include activities in wholesale and retail trade, breaking bulk, re-packaging logistics, warehousing and the handling and storage of goods. 
It is also in the process of converting EPZs to SEZs to allow for a wider range of economics activities.

Nigeria currently has 25 zones either under construction or in the planning phase. South Africa currently has 10. The Democratic Republic of the Congo (DRC) and Djibouti both note they have five planned. In Angola, there are plans in place to change the rules for the creation of SEZs that will extend the incentives offered to firms to a range of tax exemptions. In Mozambique, a special tax and custom regime is being planned for the Zambezi Valley that will run until 2025.

In Zambia, the Lumwana MFEZ is currently under development. Over the next four years it is expected to accommodate 50-60 enterprises with an output exceeding USD $\$ 1.5$ billion, of which USD $\$ 600$ million will be exported. It is also expected to lead to the creation of 6,000 jobs for the local population. SEZs and FTZs are also planned in Congo (Brazzaville), DRC, Djibouti, Gabon, Senegal, South Africa, Sudan, and Tanzania.

It is clear from the information presented in Tables 1 and 2 that SEZs are an important tool of industrial policy in SSA. It is also evident that there are a number of well-functioning SEZs in many SSA countries. It should, however, be re-emphasized that the SEZs considered in our analysis are a selected sample of the more successful SEZs. It is highly unlikely that SEZs that have failed or have closed down are documented on the online sources that we considered. As Farole (2011) points out, African SEZs have, in general, under-performed relative to expectations. The fact that there are examples of successful SEZs in SSA suggests there are important lessons to be learned from these experiences that will help in the design and development of SEZs on the continent in the future.

\section{China in Africa: opportunities and challenges}

China's engagement in Africa has intensified over the last decade. By the end of 2009, China's outward foreign direct investment (FDI) in Africa had reached a stock of US $\$ 9.33$ billion. A large share - 22 per cent, second only to mining-went to manufacturing (Lin 2011). More recently, Chinese investment in African manufacturing has accelerated. From 2009 to 2012 it was estimated to be US $\$ 1.33$ billion. The Chinese government currently offers tariff-free entry to more than 400 products from Africa's low-income countries, and the composition of exports from Africa to China is also much more diverse than with other trading partners such as the US where most exports are raw materials (Brautigam and Tang 2014). China has also become a major aid donor to Africa and a source of development policy advice.

Building on its own highly successful experience with spatial industrial policy, China has played a leading role-one largely ignored by Africa's traditional 'development partners' - in reviving interest in SEZs as a tool for industrial development. In this section we look at two aspects of China's engagement in spatial industrial policy in Africa. First, we discuss China's Economic Cooperation Zone (ECZ) initiative, which is part of its official aid programme. We then turn to a case study of recent developments in Ethiopia, the country that has most faithfully sought to replicate the Chinese model of SEZ development.

\subsection{China's African SEZ initiative}

Since about 2000, China's Ministry of Commerce has supported the development of six ECZs in Africa. Agreements were signed to develop zones in Zambia, Egypt, Nigeria, Mauritius and 
Ethiopia. Planning for most zones was initiated in the early to mid-2000s but dates back as far as 1994 in the case of Egypt (Brautigam and Tang 2014). By 2015 only three zones were in operation, in Zambia, Egypt and Ethiopia. The other four zones were still under construction. ${ }^{6}$ All of the zones are designed to support manufacturing and most are concentrated on traditional mass manufacturing sectors.

In order to create the ECZs the Chinese government issued tenders for Chinese firms to develop the zones and private zone developers have played an important role in the initiative. The Chinese private developers construct the infrastructure inside the zones and are responsible for day to day operation. The Chinese government provided grants to the developers of between US $\$ 29$ and US $\$ 44$ million in addition to long term loans of up to US $\$ 294$ million. Access to subsidies was performance-based. The Chinese government has also undertaken to promote the zones among Chinese firms looking to offshore low-end manufacturing. African governments are responsible for regulating the zones and providing fiscal incentives to potential clients. Incentives usually include tax holidays, waivers on import tariffs for raw materials and inputs and restrictions on strike activity. Host governments are also responsible for providing infrastructure outside the zones.

While it is too early to tell whether the Chinese ECZs will be successful, there are some features of the model that make it different from previous failed attempts to develop SEZs in Africa. First, the business model is different. Typically, SEZs are developed and operated by national governments. In the case of the ECZs, private Chinese firms are responsible for the development of the zones and so are likely to be more market focused and driven by profitability. Second, the tender process for selecting the Chinese firms responsible for developing the zones took account of the developer's ability in designing and constructing infrastructure. The designs of many of the zones are based on successful Chinese SEZs. This suggests that at least from an efficiency point of view these zones are likely to deliver.

The metric used to determine success is important. In terms of their role in industrializing, the success of ECZs in Africa will depend on the extent to which they attract a diverse pool of local and international investors, create jobs and foster technology transfer and learning. While the full range of investors into the zones is not yet known, it is expected that the vast majority will be Chinese. In fact, some host governments have actively prevented local firms from locating in the zones stating that they want them to be a vehicle for attracting FDI (Mauritius). This raises concerns over the lack of linkages between the ECZs and the domestic manufacturing sector, as this will limit the extent to which knowledge transfers to the local economy will occur.

\subsection{Ethiopia: implementing the Chinese model}

In autumn 2015, the Government of Ethiopia launched its second Growth and Transformation Plan (GTP II). GTP II set out a range of development priorities to achieve middle-income status by 2025 , including a focus on fostering industrialization. In implementing the new plan, Ethiopia has embarked on what is arguably the region's most ambitious set of spatial economic policies, largely modeled on its understanding of the Chinese experience. Ethiopia's large geographic size and the poor state of its infrastructure, make transport costs high and promote spatial concentration of industry. Manufacturing firms are present in all the large urban centres of the

\footnotetext{
${ }^{6}$ In addition to the official ECZs, a number of private Chinese firms have established industrial parks and free trade zones in Africa on their own. Very little information is available on the process involved in the establishment of these zones and their success to date.
} 
country, and there is a relatively high concentration of manufacturing production in Addis Ababa and its neighbouring areas. Because Ethiopia is landlocked, exporting firms tend to be located near to access corridors such as the airport at Addis Ababa and the Djibouti rail corridor. Under GTP II the government has embarked on a programme to develop both public and private SEZs.

The Ethiopian Industrial Parks Development Corporation (IPDC) was established in 2014 to build and maintain federal industrial parks. The IPDC is tasked with both pre- and post-investment services, working collaboratively with the Ethiopian Investment Commission (EIC) and Ethiopian Revenue and Custom Authority to provide a 'one-stop-shop' service for investors in its zones. The IPDC is charged with providing serviced industrial land and pre-built sheds that are in the words of its enabling legislation: 'equipped with all-encompassing utilities and infrastructure facilities that conform to international standards.' The Ethiopian Investment Board (EIB), chaired by the Prime Minister, provides overall direction and policy coordination.

There are 16 publicly owned industrial parks operating or planned by the IPDC. Bole Lemi Phase 1 was the first industrial park developed by the government. It started operations in 2015 focusing on textile and leather production for export. The second, Bole Lemi Phase 2 (186 hectares), is currently being developed in collaboration with the World Bank. It will contain, an ICT village aiming to promote growth in a new sector. The most recently opened public sector industrial park, Hawassa, was designed and constructed by the China Communications Construction Company in less than a year. The park will house 15 textile and garment firms from China, India, the USA, Sri Lanka, and six Ethiopian companies. The zone has 35 factory sheds and 19 buildings. It is also Ethiopia's flagship 'eco-industrial park', mostly powered by hydro-electricity.

In addition to the publicly developed zones, there are a growing number of privately owned industrial parks. The Eastern Industry Zone was developed by an expatriate Chinese investor in 2007 under the ECZ initiative outlined above. It is located in Oromia region around Dukem, a small town 35 kilometres southeast of Addis Ababa. After a slow start, the number of enterprises in the zone, which covers 4 square kilometres, is expected to reach 50 in $2016 .^{7}$ The zone is best known as the site of the Huajian Group, a Chinese company that produces shoes for brands such as Guess and Calvin Klein. Huajian Group itself is now planning to invest US\$2.2 billion in an industrial zone of its own located around Lebu area in the south-western outskirts of Addis Ababa. The Modjo 'Leather City' Industrial Zone, under development by Taiwanese footwear manufacturer George Shoes, is designed to be occupied by new leather tanneries, surrounded by services and ancillary activities, including a common waste water treatment plant and centralized services for chrome recovery and by-products processing. ${ }^{8}$

Both the public and private SEZs are focused on specific manufacturing sectors, such as textiles and apparel, leather and integrated agro-processing. Significant infrastructure is already in place or under construction, particularly on-site facilities including electrical sub-stations, electrical installations, domestic water supply and sanitation. The zones will also include some support services, for example training rooms for workers, customs offices, health clinics and offices for banks, greenery and other public amenities.

The current population of firms in Bole Lemi I and Hawassa reflects the tendency for firms of similar types to agglomerate. Bole Lemi I is entirely occupied by apparel and footwear

\footnotetext{
${ }^{7}$ http://africa.chinadaily.com.cn/weekly/2015-07/17/content_21309023.htm (Accessed November 2016).

8 AddisBiz.com (2015), available at: http://addisbiz.com/ethiopian-business-news/169-chinese-corporation-toconstruct-hawassa-industrial-park-for-246m (Accessed June 2016).
} 
manufacturers. Moreover, the Huajian shoe factory in Dukem, and the developing Mojo Leather District are all spaced along the Addis Ababa-Adama corridor. Because these firms require similar inputs and involve quite similar working and management practices, the proximity of the different industrial zones to each other encourages agglomeration benefits.

The rapid growth of SEZs in the area around Addis Ababa points to an important complementarity between spatial industrial and urban development policies. To be successful SEZs need to be integrated with the surrounding cities. In Addis Ababa road networks and public transportation are already stretched. In Bole Lemi Phase I it has been challenging to get workers to the site, which is not well served by public transportation, and some tenants have provided factory shuttle buses. Upon completion of Phase 2, both sites are expected to create up to 75,000 jobs (in two shifts), significantly worsening existing transportation bottlenecks. Because the zones were built on agricultural land, the immediate areas around the sites lack housing and have poor educational and medical services. While there is intent to build residential and community services, they are unlikely to be in place when Bole Lemi Phase II begins operation.

\section{What is needed for effective SEZ development?}

Africa has been a relative latecomer to the use of SEZs, and part of the reason for the failure of African SEZs may simply be poor timing. The rapid growth and contribution of economic zones to export-led growth in East Asia was in part driven by an unprecedented era of globalization (Farole and Moburg 2014). Because most African countries launched their programmes later, they faced a more competitive environment, especially after the expiration of the MFA. But bad timing alone does not tell the whole story. Many African zones have failed to take off due to a lack of basic infrastructure and institutions.

\subsection{Infrastructure and institutions}

A number of reforms to African SEZ programmes can be undertaken to improve their effectiveness. The most critical is to raise the infrastructure and institutional standards of SEZs to the levels needed to attract regional and global investors. ${ }^{9}$ For an SEZ to be successful reliable infrastructure is crucial. For EPZs customized facilities such as IT centres, reliable broadband, power supply, security services, financial services, transportation and logistics are also essential. Farole (2011) found that while in most cases African zones had physical environments that were more attractive than the overall national economy, these improvements were not sufficiently attractive to export-oriented investors with global alternatives. For example, the reported average downtime from lack of electrical power in African SEZs was 44 hours per month compared with only four hours per month in non-African SEZs. As the Ethiopia case demonstrates, lack of investment in connective and social urban infrastructure outside the zone represents another vulnerability.

Institutions supporting SEZs, such as customs clearance, legal requirements for exporting and the regulatory regime must also function well. Customs clearance times in African zones are double that of their non-African competitors (Farole 2011). In Tanzania, for example, only 20 per cent of SEZ firms have access to on-site customs clearance, and clearance times for imports into SEZs

\footnotetext{
${ }^{9}$ Farole (2011) finds that among the African countries surveyed, the top three factors determining investors' decisions to locate in an SEZ were: cost and quality of utilities, access to efficient transport, and the business regulatory environment.
} 
averaged 19 days, compared with 14 days for the economy as a whole. Other institutional problems that have plagued African SEZ programmes include insufficient strategic planning, poor choices in terms of location, weak implementation capacity and a lack of internal coordination. The management of SEZs in Africa has also been problematic. Farole's (2011) case studies found that political appointees or former civil servants with little understanding of the private sector managed many of the SEZs. Moreover, SEZs were not linked with other institutions responsible for industrial policy, such as the FDI promotion agency.

Most African SEZs are disconnected from domestic value chains, limiting their utility in the transfer of capabilities. In many countries, current policies and regulations in export processing zones place serious obstacles in the way of linkages between foreign and local firms. The architecture of most African EPZs is 'closed'. in the sense that excessive concern with evasion of tariffs and other taxes by local investors has led to rules that choke off purchaser-supplier relationships between firms in the zone and domestic firms outside. In addition, in many countries regulations restrict the movement of managers and workers between EPZs and the rest of the economy. A key area for action is to remove these obstacles.

\subsection{Leadership and coordination}

After more than 50 years of experience, there is no lack of international expertise on how to design and implement a successful SEZ programme. Legions of international consultants offer technocratic expertise, and countries with successful SEZs_-such as China and Singaporeprovide technical assistance and financial support for SEZ development as part of their bilateral aid programmes. Many African governments have been the recipients of these initiatives, yet little seems to have changed in the ability of Africa's SEZ programmes to contribute to more robust industrial growth. This suggests that the failure of spatial industrial policy in Africa reflects a deeper set of institutional and governance failures in the practice of industrial policy.

While the practice of industrial policy is both complex and country specific, successful efforts to implement industrial policy share some common characteristics (Page and Tarp 2017, forthcoming). Foremost among these is the role of leadership. One of the most important success factors for SEZ programmes in East Asia was strong support and active commitment to the programme at the highest levels of political leadership (Farole and Moburg 2014). In China and Viet Nam for example the senior government and party leadership were publicly committed to the success of SEZs. This signalled to officials that the economic zone programme was a central instrument in the government's industrial development strategy.

One virtue of having a high-level champion is that it identifies a person who has the job of explaining why the policy agenda looks as it does and who can be held politically responsible for things going right or wrong. When the responsible party is the head of state or government it also raises both the visibility of the industrial policy process and the level of accountability for its implementation. In Africa, all too frequently top political leadership has chosen to delegate the industrial development agenda to lower levels of government, and, while political leaders have periodically promoted SEZs, they have failed to maintain consistent links between the SEZ programmes and wider strategies for industrialization.

Many African SEZs have failed to deliver on promises of world-class infrastructure and a quality investment environment, because of difficulty in coordinating across various government agencies. In the extreme, coordination failures among institutions have resulted in the creation of multiple, overlapping SEZ regimes. For example, in 2002 Tanzania launched an EPZ programme, led by its National Development Corporation. Just four years later, and before the EPZ programme was 
operational, the government passed a law setting up an SEZ regime under the authority of the Ministry of Planning, Economy, and Empowerment. Faced with two competing programmes, the government finally enacted the Economic Zones Law of 2011, which unified the EPZ and SEZ programmes. Not surprisingly, the long delays in clarifying the institutional and regulatory regime have resulted in a slow start for SEZs in Tanzania (Kinyondo et al. 2016; McMillan et al. 2017). Ethiopia faces similar risks as municipal and national industrial parks begin to compete for clients.

The most common coordination problems occur in implementation. Frequently institutions with very different objectives and incentives fail to work together toward a common goal. For example, currently about 300 enterprises operate in Ghana's export processing zones. EPZ manufacturing firms are involved in food processing, wood and veneer processing, processing of shea nuts and oil seeds, lubricants and biofuels, garments, and the manufacture of food processing machines and spare parts. The zones also host such tradable services as data processing, telecommunications, and software development. The sheer variety of firms in the zones raises a red flag. In an economy like Ghana, clusters of firms connected along a value chain are more likely to realize significant firm-level productivity gains than geographical concentrations of unrelated firms. One reason for the heterogeneity of firms is that neither the FDI agency nor the SEZ management had a strategy for attempting to attract firms in the same or closely related value chains into the zones.

There are few African countries where central SEZ authorities have the decision-making power over regulatory activities. In Lesotho, when a one-stop-shop for investors was introduced in 2007, the physical co-location of agencies did very little to resolve the problems of facilitation, because officers still reported to their individual ministries. The head of the one-stop-shop thus had no authority to ensure that the officers worked efficiently and provided quality service (Farole 2011). In many cases, including Tanzania, Nigeria, and Kenya, the lack of a formal institutional link between agencies, such as sitting on each other's boards or forming joint committees, contributes to the operational disconnect.

To attract investment the SEZ Authority needs to be able to streamline government services (including licensing, registration, utility connections, dispute settlement, and fee setting) and resolve disputes. Governments will need to take a very hard look at how they select and support their SEZ managers. Where zone authorities have played this role effectively they, together with the Investment Promotion Agency, have enjoyed a large measure of autonomy and have most often been placed under the Office of the President or of the Prime Minister. An autonomous agency has the benefit of removing day-to-day political considerations that may distort incentives in the operation of the SEZ programme. Linking the agency to a high-level central authority facilitates coordination across various government ministries and agencies. By contrast, if the SEZ authority reports to a particular ministry such as the Ministry of Trade and Industry, other ministries have little incentive to coordinate their activities to support its aims

\section{$7 \quad$ Summing up}

To date, Africa's experience with spatial industrial policy has been largely disappointing. Most African SEZs have failed to reach the levels of physical, institutional, and human capital needed to attract global investors. African zones have low levels of investment and exports, and their job creation impact is limited. They have few links with the domestic economy, and from the perspective of agglomeration it is notable that African SEZs have a much lower density of enterprises within the geographical boundaries of the SEZ than zones in Asia or Latin America. 
To meet the region's ambitious industrial development goals, it is essential for African governments to upgrade SEZ performance to international standards. This requires much more than setting up an SEZ authority and waiting for investors to come. Many African SEZs have failed to deliver on promises of world-class infrastructure and a quality business environment, because of the difficulty in coordinating across the local and national organizations that control public services and institutions outside the zones.

Stronger leadership and better institutional coordination are essential to the future success of spatial industrial policy in Africa. The senior political leadership must own the industrial policy agenda, explain it and be willing to be held politically responsible for it. SEZ authorities must be able to work pragmatically across the whole of government to get things done. When the SEZ authority directly reports to the head of state it raises visibility, improves the capacity to resolve conflicts and enhances the level of accountability.

\section{References}

Ayadi, M., and W. Mattoussi (2014). 'Disentangling the Pattern of Geographic Concentration in Tunisian Manufacturing Industries’. WIDER Working Paper 2014/072. Helsinki: UNU-WIDER.

Brautigam, D., and X. Tang (2014). 'Going Global in Groups: Structural Transformation in China’s Special Economic Zones Overseas’. World Development, 63: 78-91.

Chete, L.N., J.O. Adeoti, F.M. Adeyinka and O. Ogundele (2014) 'Industrial Development and Growth in Nigeria: Lessons and Challenges'. WIDER Working Paper 2014/019. Helsinki: UNU-WIDER.

Chhair, S., and C. Newman (2014). 'Clustering, Competition, and Spillover Effects: Evidence from Cambodia'. WIDER Working Paper 2014/065. Helsinki: UNU-WIDER.

Combes, P. and L, Gobillon (2015) 'The Empirics of Agglomeration Economies'. Handbook of Regional and Urban Economics, 5:247-348.

Duranton, G. and D, Puga (2004) 'Micro-foundations of Urban Agglomeration Economies'. Handbook of Regional and Urban Economics, 4: 2063-2117.

Farole, T. (2011). Special economic zones in Africa: comparing performance and learning from global experiences. Washington, DC: World Bank.

Farole, T. and L. Moburg (2014). 'It Worked in China, so Why Not in Africa? The Political Economy Challenge of Special Economic Zones'. WIDER Working Paper 2014/152. Helsinki: UNU-WIDER.

Fujita, M., P.R. Krugman, and A.J. Venables (1999). The Spatial Economy: Cities, Regions and International Trade. Cambridge, MA: MIT Press.

Hamada, K. (1974) 'An Economic Analysis of The Duty-Free Zone'. Journal of International Economics, 4(3): 225-241.

Helsley, R.W., and W.C. Strange (1990). 'Matching and agglomeration economies in a system of cities'. Regional Science and Urban Economics, 20(2): 189-212.

Howard, E., C. Newman, and F. Tarp (2016). 'Measuring Industry Agglomeration and Identifying the Driving Forces'. Journal of Economic Geography, 16(5): 1055-78. 
Howard, E., C. Newman, J. Rand, and F. Tarp (2014). 'Productivity Enhancing Manufacturing Clusters: Evidence from Vietnam'. WIDER Working Paper 2014/071. Helsinki: UNU-WIDER.

Howard, E., C. Newman, and J. Thijssen (2011). 'Are Spatial Networks of Firms Random? Evidence from Vietnam’. WIDER Working Paper 2011/087. Helsinki: UNU-WIDER.

Johansson, H., and L. Nilsson (1997). 'Export Processing Zones ss Catalysts'. World Development, 25(12): 2115-28.

Kinyondo, A., C. Newman, and F. Tarp (2016). 'The Role and Effectiveness of Special Economic Zones in Tanzania'. WIDER Working paper 2016/122. Helsinki: UNU-WIDER.

Krugman, P.R. (1991). 'Increasing Returns and Economic Geography'. Journal of Political Economy, 99: 483-99.

Lin, J. (2011). 'From Flying Geese to Leading Dragons: New Opportunities and Strategies for Structural Transformation in Developing Countries'. Policy Research Working Paper 5702. Washington, DC: World Bank.

Madani, D. (1999). 'A Review of the Role and Impact of Export Processing Zones'. Policy Research Working Paper 2238. Washington, DC: World Bank.

Marshall, A. (1920). Principles of Economics. London: Macmillan.

Miyagiwa, K.F. (1986). 'A Reconsideration of the Welfare Economics of a Free-Trade Zone'. Journal of International Economics, 21(3): 337-50.

McMillan, M., J. Page, and S. Wangwe (2017) 'Unlocking Tanzania's Manufacturing Potential'. In C.S. Adam, P. Collier, and B. Ndulu (eds), Tanzania: The Path to Prosperity. Oxford: Oxford University Press.

Newman, C., J. Page, J. Rand, A. Shimeles, M. Söderbom, and F. Tarp (2016a). Made in Africa: Learning to Compete in Industry. Washington, DC: Brookings Institution Press.

Newman, C., J. Page, J. Rand, A. Shimeles, M. Söderbom, and F. Tarp (eds) (2016b). Manufacturing Transformation: Comparative Studies of Industrial Development in Africa and Emerging Asia. London: Oxford University Press.

Overman, H.G., and D. Puga (2010). 'Labour Pooling as a Source of Agglomeration: An Empirical Investigation'. In E. Glaeser (ed.), Agglomeration Economics. Chicago: University of Chicago Press.

Overman, H., and T. Venables (2005). 'Cities in the Developing World'. CEP Discussion Paper 695. London: LSE.

Page, J. (2012). 'Aid, Structural Change and the Private Sector in Africa'. WIDER Working Paper 2012/21. Helsinki: UNU-WIDER.

Page, J., and F. Tarp (eds) (2017, forthcoming). The Practice of Industrial Policy: Government-Business Coordination in Africa and East Asia. Oxford: Oxford University Press.

Schmitz, H. (1995). 'Collective Efficiency: Growth Path for Small-scale Industry'. Journal of Development Studies, 31: 529-66.

Schrank, A. (2001). 'Export Processing Zones: Free Market Islands or Bridges to Structural Transformation?'. Development Policy Review, 19(2): 223-42.

Siba, E., M. Söderbom, A. Bigsten, and M. Gebreeyesus (2012). 'Enterprise Agglomeration, Output Prices, and Physical Productivity: Firm-Level Evidence from Ethiopia'. WIDER Working Paper 2012/085. Helsinki: UNU-WIDER. 
Sonobe, T., and K. Otsuka (2006). Cluster-Based Industrial Development: An East Asian Model. Basingstoke: Palgrave Macmillan.

Sutton, J. (2012). Competing in Capabilities: The Globalization Process. Oxford University Press.

World Bank (2009). World Development Report 2009. Washington, DC: World Bank. 


\begin{tabular}{|c|c|}
\hline Country & Source \\
\hline Angola & $\begin{array}{l}\text { US Department of State } 2015 \text { Investment Climate Statement for Angola } \\
\text { Ernst Young-Global Tax Alert }\end{array}$ \\
\hline Benin & $\begin{array}{l}\text { Honorary Consulate of the Republic of Benin in Izmir \& US Department of State } 2015 \\
\text { Investment Climate Statement for Benin }\end{array}$ \\
\hline Cameroon & US Department of State Investment Climate Statements for Cameroon \\
\hline Congo (Brazzaville) & US Department of State Investment 2015 Climate Statement for the Republic of Congo \\
\hline Cote d'Ivoire & US Department of State Investment 2015 Climate Statements for Cote d'Ivoire \\
\hline DRC & DR Congo Investment Promotion Agency \\
\hline Djibouti & Djibouti Ports \& Free Zones Authority (djiboutifz.com) \\
\hline \multirow{2}{*}{ Eritrea } & US Department of State 2015 Investment Climate Statement for Eritrea \\
\hline & 'Eritrea to launch Massawa, Assab free trade zones', Reuters (www.goo.gl/fRa20l) \\
\hline \multirow[t]{2}{*}{ Gabon } & $\begin{array}{l}\text { Agence de Promotion des Investissements et des Exportations } \\
\text { GSEZ }\end{array}$ \\
\hline & US Department of State Investment 2015 Climate Statements for Gabon \\
\hline The Gambia & $\begin{array}{l}\text { US State Department Investment Climate Statement for The Gambia } \\
\text { Gambia Investment \& Export Promotion Agency }\end{array}$ \\
\hline Ghana & Ghana Free Zones Board \\
\hline Kenya & $\begin{array}{l}\text { US Department of State } 2015 \text { Investment Climate Statement for Kenya } \\
\text { EPZA Kenya Annual Performance Report } 2014\end{array}$ \\
\hline Madagascar & US State Department Investment Climate Statement for Madagascar \\
\hline Malawi & $\begin{array}{l}\text { The Decline of EPFs under the EPZ Regime in Malawi 2015-Ministry of Industry \& Trade } \\
\text { Malawi }\end{array}$ \\
\hline \multirow[t]{3}{*}{ Mauritius } & Mauritius Board of Investment \\
\hline & Mauritius Freeport Development \\
\hline & US State Department Investment Climate Statement for Mauritius \\
\hline \multirow[t]{2}{*}{ Mozambique } & US State Department Investment Climate Statement for Mozambique \\
\hline & $\begin{array}{l}\text { Special Economic Zones \& Economic Transformation: Maximising the Impact of the SEZ } \\
\text { Programme in Mozambique-USAID \& Mozambique Support Programme for Economic \& } \\
\text { Enterprise Development } \\
\text { GAZEDA (Special Economic Zones Office) }\end{array}$ \\
\hline \multirow[t]{3}{*}{ Namibia } & Walvis Bay Export Processing Zone Management Company \\
\hline & US State Department Investment Climate Statement for Namibia \\
\hline & Republic of Namibia Ministry of Industrialisation Trade \& SME Development \\
\hline \multirow[t]{2}{*}{ Nigeria } & Nigeria Export Processing Zones Authority \\
\hline & US State Department Investment Climate Statement for Nigeria \\
\hline \multirow[t]{2}{*}{ Rwanda } & Rwanda Development Board \\
\hline & US State Department Investment Climate Statement for Rwanda \\
\hline \multirow[t]{2}{*}{ Senegal } & Invest in Senegal \\
\hline & Export Promotion Authority (APIX) \\
\hline Sierra Leone & $\begin{array}{l}\text { US State Department Investment Climate Statement for Sierra Leone } \\
\text { First Step Economic Opportunity Zone }\end{array}$ \\
\hline South Africa & $\begin{array}{l}\text { Coega Development Corporation } \\
\text { US State Department Investment Climate Statement for South Africa }\end{array}$ \\
\hline Sudan & Ministry of Investment \\
\hline Tanzania & Export Processing Zones Authority Tanzania \\
\hline Togo & US Department of State Investment Climate Statement for Togo \\
\hline Uganda & Uganda Free Zones Authority \\
\hline \multirow[t]{2}{*}{ Zambia } & Industrial Development Corporation Zambia \\
\hline & Ministry of Commerce Trade \& Industry Zambia \\
\hline \multirow[t]{2}{*}{ Zimbabwe } & Zimbabwe Investment Authority \\
\hline & US State Department Investment Climate Statement for Zimbabwe \\
\hline
\end{tabular}

